\title{
UNDERSTANDING THE HUMANITY OF PROPHET MUHAMMAD AND JESUS: A WESTERN PEACEBUILDING PHASE TOWARDS ISLAM
}

\author{
Fahd Mohammed Taleb Saeed Al-Olaqi \\ University of Jeddah and King Abdulaziz University
}

\begin{abstract}
Western accounts of Prophet Muhammad become more academic to understand his prophethood compared to Jesus the Christ. On a peacebuilding bridge, Craig Considine takes the step up in far-sighting the same divine words in Prophet Muhammad and Jesus Christ. He calls them brothers to other evangelic prophets. The common humanity traits of Muhammad \& Jesus can be a constructive stand for better understanding. The non-violent phase of Western change amends some information about Islam and its Prophet that may help uproots unspeakable hatred against Muslims. Karen Armstrong's writings dispose derogatory and hostile misrepresentation of Islam and its Prophet. The establishment of academic consciousness about the Prophethood of Muhammad contributes into peace and tolerance in the world.
\end{abstract}

Keywords. The Qur'ān, Prophet Muhammad, Jesus Christ, prophethood, peacebuilding

DOI: https//doi.org/10.3176/tr.2021.4.06

Received 7 August 2021, accepted 21 September 2021, printed and available online 10 December 2021

\section{Introduction}

The peacebuilders have positive understanding and constructive arguments about Islam and Messenger Muhammad (Peace and Blessing Upon Him) (570-633). One of the widespread arguments that Muhammad (PBUH) was a righteous person who donated his lifetime to serve the pagans of the Arabian Peninsula by appealing Prophethood. This opinion is apparently natural but censoriously oversees his 
generation triumphs and his power on the antiquity of human race. George Bernard Shaw (1856-1950), Irish writer and Nobel laureate, had studied Prophet Muhammad as an amazing man, and he had found him away from provoking Jesus the Christ. He stated that the Prophet must be so-called 'the Saviour of Humanity'. ${ }^{1}$ Uundoubtedly Armstrong has formed an image of Prophet Muhammad (PBUH) that is obviously more compassionate and less prejudiced than any other non-Muslim researcher did. She succeeds to expose his compassionate and subtle character. For instance, Karen Armstrong's Muhammad: A Biography of the Prophet (1992) seems a tremendous resource to study the lifespan and traditions of Muhammad (PBUH) without the usual Western bias.

The Western library nowadays contains authentic Islamic information. Making a straightforward image of Prophet Muhammad (PBUH) is part of facts. Therefore, Craig Considine and Karen Armstrong became controversial social commentators since they stand for Western prejudice against Prophet Muhammad. Considine is the first Western writer who used Hadiths from authentic Sunni sources. The return to reason, freedom, and tolerance perspective, Christians and Muslims can reach to a peace ground in it to live together in harmony. For non-Muslims, Craig Considine's Writings is a guide to understand Muhammad and Islam.

Islam is free of the blasphemy. Islam means 'submission to God'. The term 'Muslim' means 'submitted' to the Deity, the Creator. The Qur'ān reports this meaning that "It was appropriate to apply it to Abraham, who along with his son whom God had told him to sacrifice'surrendered himself (to God)" (The Glorious Qur'ann, 37: 103). Islam is the corresponding verbal noun with the meaning 'surrender' (to God) and is a good name for a religion. Islam is the trust in only One Divinity, whose title is Allah, 'God, the Creator'. Islam has the same revelation assumed to all the prophets, starting from Adam to Noah passing to Abraham and his offspring Moses and Jesus, and lastly to Muhammad, the last messenger (Peace and Blessings be Upon Them). They all carried the similar communication: worship truly and only Allah the Maker.

Western anti-Muhammad is an exclusively aggressive and biased move. Evangelic terms to tab Muslims and Islam like Mohammedans and Mohammedanism are pejorative but escaped the modern Western diction. Likewise, for many centuries Islam is terrorism in the West. Since the seventh century, the Western religious institutions had proposed Islam and its Messenger Muhammad (PBUH) as a theological challenge. Christian authors slanted the reputation of the Prophet with offensive titles such as anti-Christ, impostor, and devil. Because of conversion to Islam, Norman Daniel states that for past centuries "Christians have defended their faith in the Trinity and Incarnation from Muslim attack; and they have in turn attacked Islam for accepting the claim of Muhammad to be the vehicle of Revelation" (Daniel 1993: 275). William Watt finds out the same judgments and remarks that "none of the great figures of history is so poorly appreciated in the West as Muhammad" (Watt 1953: 52).

1 See "Prophet Mohammed in fair Western eyes" to read more. Available online at $<\mathrm{http}: / /$ imanway1. com/eng/index2.php?option $=$ com_content\&do_pdf $=1 \& i d=57>$. Accessed on 07.08.2021. 
The writings of the greatest dominant Western authors such as Norman Daniel, Thomas Walker Arnold, William Watt and William Muir, provide reliable knowledge for bibliophiles which made non-Muslims and Muslims to come together against all methods of misrepresentation, and to compete against all manifestations of errors along with academic investigations to admit a new-fangled methodology as a significant phase to an actual understanding the Prophethood of Muhammad (PBUH). A critical evaluation of the perception of the image of Islam is in the Western discourse. Craig Considine works on his Christian audience to teach them about Christian-Muslim relations. The humanity of Prophet Muhammad (PBUH) is part of Jesus message. It is a modest challenge to bring into light the information about Islam with an investigation to the accounts of Western travellers. It is an examination of the reasons of incessant misinterpretation of Western writers in their portrayal of the image of Prophet Muhammad (PBUH). For example, Jack D'Amico has detected:

The problem of containing Islam, politically and intellectually, was made more difficult by those respects in which Islamic culture was actually superior. ... A more potent and seductive foe, Islam had to be represented as a dangerous distortion of the true Church, a parody of civilization, its Muhammad a false prophet, its Jihad a perversion of the Crusade, its book, the Koran, a collection of errors and lies that mocked the Bible (Vitkus 1999: 271).

This negative insincerity brands the expansion of Islam as a divine religion unconceivable. The European historian Lamartine writes positively about Muhammad (PBUH) as a "Philosopher, orator, apostle, legislator, warrior, conqueror of ideas, restorer of rational dogmas, of a cult without images; the founder of twenty terrestrial empires and of one spiritual empire, that is Muhammad. As regards all standards by which human greatness may be measured, we may well ask, is there any man greater than he?" (Lamartine 1854: 276-277). Likewise, Gibbon and Ocklay's History of the Saracen Empire (1870), remark on the Prophet saying, "I believe in One God and Mahomet the Apostle of God' is the simple and invariable profession of Islam. The intellectual image of the Deity has never been degraded by any visible idol; the honours of the prophet have never transgressed the measure of human virtue, and his living precepts have restrained the gratitude of his disciples within the bounds of reason and religion." (Gibbon and Ocklay 1870: 54).

\section{Modern West admired Prophet Muhammad}

Prophet Muhammad has been appreciated in modern history. He is one, if not for many the first of the great human beings who changed the world. Human history has never acknowledged such a comprehensive conversion of a nation or a country before and ever since. For the past fourteen centuries, some high rank scholars admired Islam. There are many scholars, truth-seekers, researchers, professors, and each a 
radiant star in our knowledgeable flora and fauna, have a respect and admiration to the human mission of Prophet Muhammad compared to Jesus Christ. The modern Western academic awareness such as the enlightening writings of Robert Burton's Pilgrimage to Meccah and Madina (1893), John Byng Wavell's A Modern Pilgrim in Mecca (1918), and Watt's Muhammad's Mecca (1953) and Muhammad's Medina (1964) established a novel atmosphere in on behalf of Muhammad as a Prophet for human beings. They enlightened the West from the outdated farfetched views and the principal radical and sacred prejudice against Muhammad. They sought objective and accurate knowledge and scholarly works.

Modern writers such as Craig Considine and Karen Armstrong think it is impossible to argue that Muslims have been since Muhammad's death, remain in error. Therefore, their understanding of Islam and its prophet improves the Western presentation of Muhammad (PBUH) as a quiet great personality, one who cannot but be serious. He was to enlighten all God's creatures. Thomas Carlyle states that 'Muhammad is a great reformer'. "Muhammad was the man of truth and fidelity, true in what he did, in what he spoke, in what he thought; always meant something, a man rather taciturn in speech, silent when there was nothing to be said, but pertinent, wise, sincere, when he did speak, always throwing light on the matter" (Carlyle 2001: 158).

Unlike numerous Western Orientalists schooled to refute facts and form uncertainties to reject Islam, some modern Western Orientalist academicians unjustly claim that Muhammad (PBUH) had invented the revelations from God the Creator (Watt, 1961: 59). Sincere and educated readers are misinformed and led to effectively and entirely convicting Islam and its Prophet. For example, Norman Daniel says that "the use of false evidence to attack Islam was all but universal" (Daniel 1993: 267). On the other hand, some independent investigators like Professor William Watt concludes his life-research writings that Muhammad 'had been given a special commission by God' (Watt 1961: 3). Likewise, Geoffrey Parrinder rejects the misunderstanding of Prophet Muhammad in the West. He says:

No great religious leader has been so maligned as Prophet Mohammed. Attacked in the past as a heretic, an impostor, or a sensualist, it is still possible to find him referred to as "the false prophet." A modern German writer accuses Prophet Muhammad of sensuality, surrounding himself with young women. This man was not married until he was twenty-five years of age, then he and his wife lived in happiness and fidelity for twenty-four years, until her death when he was forty-nine. Only between the age of fifty and his death at sixty-two did Prophet Muhammad take other wives, only one of whom was a virgin, and most of them were taken for dynastic and political reasons. Certainly the Prophet's record was better than the head of the Church of England, Henry VIII (Parrinder 1976: 121).

The non-violent ways of change enlighten the Western public. The earlier perception that Islam is inferior to the West has no values in common with other cultures, and rather than a religion it is a violent political ideology. Islamophobia 
occurred in premise previously to the terrorist outbreaks of September 11, 2001, but it enlarged in rate of recurrence throughout the past decade. As the West is still spur-of-the-moment to comprehend the title 'prophet' aimed at Muhammad (PBUH) (Khan 2020), a cross-cultural peacebuilding can play a positive role to defuse misunderstanding and destructive disputes. For instance, Forward remarks, "Christians deceive themselves when they think that, by calling Muhammad a prophet, they mean the same or even a comparable thing" (Forward 1997: 120). Karen Armstrong thinks that some Christian thinkers regard Prophet Muhammad (PBUH) as a political and spiritual intellect with passing on him the title 'prophet' (Armstrong 1992: 14). The mission of Prophethood is also a political and religious job like that of Prophet David and his son Solomon (PBUH). Therefore, the peacebuilders like Craig Considine thinks that Jesus Christ and Muhammad are the greatest greats in history. Craig Considine realizes that Allah the Creator guided Muhammad (PBUH), foreshadowing Islam, the religious conviction of oneness of God and heavenly leadership, a communication of union, communal friendship and coexistence amongst the humankind, to establish peacetime permeate the earth and lease righteousness, equivalence, harmony and contributions succeed over prejudice, discrimination, hostility and terrific associations (Khan 2020: 75). Therefore, the steady modification of the portrayal of the Islam and its Messenger is a production of consciousness and enquiry. The reasonable and truthful material had provided the world library with truth about Islam and Muhammad.

\section{Jesus and Muhammad, the Prophets}

European researchers currently comprehend the faith of monotheism. Since it is entirely in line with the Bible and the Qur'an. Prophets Jesus and Muhammad are monotheists calling to the same God, the Creator. In a peacebuilding bridge, Prophet Muhammad resembles Prophet Jesus, the Christ in peace and humanity. Craig Considine strongly believes that "By turning to their teachings, we can see that these two prophets are brothers, not foes"2. Craig uses Prophet Muhammad's words compared to what Prophet Jesus said as the follow of God's revelation. For instance, he thinks that Jesus (PBUH) and the Prophet were proponents of peace.

Jesus told his followers: "Blessed are the peacemakers, for they shall be called sons of God" (Matthew 5:9). Saint Peter, one of Christ's disciples, echoed this message of goodwill by encouraging people to "turn away from evil and do good... seek peace and pursue it" (Peter 3:11). Roughly 600 years after Jesus, Prophet Muhammad revealed his revelations to the tribes of Arabia, where Muhammad was particularly adamant about establishing peace. One of the Prophet's favourite sayings was: "Forgive him who wrongs you, join him who cuts you off, do good to him who does evil to you" (Ibid).

2 Published on Huffington Post (24.04.2015). Available online at $<\mathrm{https}$ ://craigconsidinetcd. com/2015/04/24/jesus-christ-and-prophet-muhammad-followed-the-golden-rule/>. Accessed on 07.08.2021. 
The mutual humanity characters of Muhammad \& Jesus are comparatively constructive for better understanding the two prophets. For instance, Craig Considine admires the knowledge of Messenger Muhammad (PBUH) like Jesus (PBUH) in encouraging Muslims to pursue acquaintance insofar as if it is in China, Considine says:

"When I read the Qur'an, I don't interpret it as a book for Muslims, but rather for all human beings. The Qur'an (5:47) requests people to "discern what God has sent down to him." The word 'discern' is a crucial one. Literally, discern means to 'perceive something'. My mind tells me that Jesus and Muhammad have equally valuable messages. Both men shared some 'truths' but let us be real: they were human beings. They were prone to error. They made some mistakes. They missed some things. ${ }^{3}$

Craig Considine works instructively on Christian-Muslim relations. He thinks that Prophet Muhammad (PBUH) was sent to the world to reconcile the mission of Jesus. Al-Olaqi exemplifies the mission of the Prophets in saying that "Islam was and is a reasonable religion and Prophet Muhammad was and is admirable like Abraham or Jesus" (Al-Olaqi, 2016: 143). The Qur'ān reports that "Prophet Muhammad's role as the final prophet of God was to confirm the authentic teachings of previous prophets and to rectify mistakes or innovations that followers of previous monotheistic faith traditions had introduced into the original religion of humankind" (Ibid). In contrast to Jesus, Muhammad (PBUT) did not perform any spectacular miracles. The Noble Qur'an affirms:

Surely We [Allah] sent revelation unto you [O Muhammad] as We did upon Noah and the prophets after him, and as We sent revelation upon Abraham and Ishmael and Isaac and Jacob and the tribes, and Jesus and Job and Aaron and Solomon, and as We gave David the Psalms.

$$
\text { (The Glorious Qur'ān-An-Nisaa, 4: 163) }
$$

Considine escalates the Prophethood of Muhammad ruled by the right divine. Similarly, Henry Stubbe (1632-1676) in An Account of the Rise and Progress of Mahometanism with the Life of Mahomet and a Vindication of Him and His Religion from the Calumnies of the Christians states that "God is one and has no partners" (Stubbe 1954: 192). Therefore, Muslim scholars have authentic sources to informative, theological and law knowledge from the Qur'an and Sunnah (Hadiths). Muhammad the servant and Messenger of Allah informs the divine message to his people and mankind. In contrast, Professor Norman Daniel acknowledges that there is no resemblance amongst the Glorious Qur'ān and other scriptures on earth subsequently the Qur'annic theme tune have nothing corresponding in the Testaments (Daniel 1993: 35). The Bible account of Divinity is lower to the Muslim account of Divinity in the Qur'ān. The Christian Deity is frail and fewer authoritative than the faultless Deity in the Islam, as in the Qur'an says that 'Allah (God) is unlike other things' (The Glorious Qur'ān, 42:11).

3 See Dr. Considine's article "Why a Christian can view Muhammad as a Prophet". (21.01.2016). Available online at $<$ https://craigconsidinetcd.com/2016/01/21/why-a-christian-can-viewmuhammad-as-a-prophet/>. Accessed on 07.08.2021. 
Considine appreciates the magnitude of the Prophet's mission in glorifying God, the Enormous which grows into manifest from His qualities of excellence, revealed in the Holy Qur'ān. He is perfect with full description and is shorn of any fault, and out there of any accusation (The Glorious Qur'ān, 57:1-6). Armstrong, Considine and other open-minded scholars uttered their assessments on Prophet Muhammad as the utmost of the benefactors of mankind. Armstrong states that "Muhammad's personality and character in the context of his times and with an open mind. Muhammad himself saw his Faith as the continuation and enhancement of those very religions" (Armstrong 1992: 42). For instance, Stubbe admits that "to defend Islam and Prophet Muhammad against the false accusations of the Christians was not available to the reader for many years" (Stubbe 1954: 149). Stubbe as well adds that "Prophet Muhammad was an extraordinary individual; he also presents a description of the physical features of the Prophet based on the classical, authentic sources of Islam" (Stubbe 1954: 149). Daniel indicates that Christian assessments on Prophet Muhammad "change the emphasis, so that the reader, through the historicoanthropological approach ... and allowed to some extent to share the Muslim awareness of the prophet" (Daniel 1993: 330-331).

In the West, Prophet Muhammad was the Anti-Christ, an untruthful prophet, an oppressor, and a sensualist. Islam was understood as nothing more than a sacrilege of Christianity and regarded as the faith of the sword in addition it was offensively dubbed Mohammedanism. The Western Christians did not accept Islam as a compatible religion beside Christianity, but they became downright hostile to Muhammad (PBUH). In their vocal attacks, the Christian leaders established a stock of prejudice, misrepresentation, falsification, and incorrect information about Islam and its Prophet. They correspondingly launched three failed Crusades to save Christians from conversion to Islam. For several contemporary Christians, an innovative method is being reserved to what they contemplate "the menace" of Islam (Khan 2020: 85). On the other hand, James Albert Michener says that "Prophet Muhammad (PBUH) was unable to read or write, but he began to dictate those inspired words which would soon revolutionize a large segment of the earth: 'There is one God"' (Michener 1955: 70). Like Prophet Abraham (PBUH), whom he used to say that he resembled, the Prophet Muhammad (PBUH) was mild, imploring, clement, and penitent, as well as gentle to believers and full of pity and compassion for them (The Glorious Qur'ān, 11:75; 9:128). According to Stubbe, "the Prophet Muhammad's teachings were cantered on the idea that paganism should be eliminated all over the world, that God is one and has no partners." (Stubbe 1954: 192). Stubbe enhances on the fact that when Prophet Muhammad sought to end paganism, he never forced anyone to enter Islam. In fact, the Prophet Muhammad himself wrote some letters that sanctioned the protection of Christians and Jews in the Arabian Peninsula (Ibid).

Prophet Muhammad was a generous and tolerant person in war and peace. Even Karen Armstrong, who takes great efforts to explain the whole thing Muhammad did, can barely retain from displaying her repulsion: 
It is probably impossible for us to dissociate this story from Nazi atrocities and it will inevitably alienate people irrevocably from Muhammad. But Western scholars like Maxime Rodinson and W. Montgomery Watt argue that it is not correct to judge the incident by twentieth-century standards. This was a very primitive society - far more primitive than the Jewish society in which Jesus had lived and promulgated his gospel of mercy and love some 600 years earlier. At this stage the Arabs had no concept of a universal natural law, which is difficult - perhaps impossible - for people to attain unless there is a modicum of public order, such as that imposed by a great empire in the ancient world (Armstrong 1992: 3).

Tolerance and virtue are indivisible parts of the Islamic faith. The Jews under the Islamic law "rarely faced martyrdom or exile, or forced conversion, and they were free to choose their residence and profession" (Lewis 1999: 131, Stillman 1979: 27). Many Qur'anic verses preach tolerance towards the Christians and the Jews; others make hostile remarks about them (which are like hostile remarks made against those who did not accept Islam). Muhammad (PBUH) interacted with Jews living in Arabia. He preached to them in hopes of conversion. He fought against and killed many "Jews, while many other Jews were befriended by him" (Laqueur 2006: 191). Yet his Muhammad (PBUH) is a momentous prototypical charisma in the widespread Muslim assessment. The Prophet was a gentleman who had been patent out from his primary adolescence, even from before his birth, by paranormal symbols and potentials. Even when one interpretations Muhammad (PBUH) in a completely nonspiritual outlook, he remains a champion.

\section{Muhammad and Jesus, Men of Peace}

Craig Considine believes that tolerance and peace to all of humanity are main parts of the instructions of Christ and Prophet Muhammad. Considine thinks that Prophet Muhammad stopped racism and myths established over Christianity and Judaism and paganism. Considine states that "I demonstrate how Muhammad desired a pluralistic society in which citizenship and equal rights were granted to all people regardless of religious beliefs and practices" (Considine 2016: 15). For Considine, Prophet Muhammad is a message carrier, a nation establisher, a founder of a country. He appreciates the code of Islamic humanoid association, the accord of source and the equivalence of human privileges in the quest of simple life in pride and liberty. The Qur'an calls on reconciliation amongst societies and countries: "O mankind! We created you from a single pair of a male and female and made you into nations and tribes so that you may know each other" (The Glorious Qur'ann, 49:13). To extend love to all human beings in a peacebuilding relationship, Craig Considine has faith in the Islamic and Christian worlds used to themselves with the rest of globe cultures and values and exposed scarcely matched illustrations of incorporation and existence, all functioned consistently and efficiently in a exclusive 
sense of alliance. For instance, Prophet Muhammad (PBUH) is acknowledged to take Jewish friends and had a Jewish spouse (Safiyya) who became a Muslim (Laqueur 2006: 192). Armstrong admires Prophet Muhammad's life as "a jihad: as we shall see, this word does not mean 'holy war', it means 'struggle'. Muhammad literally sweated with the effort to bring peace to war-torn Arabia, and we need people who are prepared to do this today. His life was a tireless campaign against greed, injustice, and arrogance" (Armstrong 2006: 7).

Many writings refer to the pre-Islamic period. Modern writer Patricia Crone describes the trade in Arabia in Meccan Trade and the Rise of Islam (1987). She agrees with various pre-Islamic references to unimpeachable Muslim authorities as well as she is surprised that "the [Western] writers ignored the part played in Muhammad's life by aba Talib" (Crone 1987: 114). Between 580 CE and $590 \mathrm{CE}$, Mecca practiced a bloody dispute, identified as Sacrilegious War, flanked by Quraish and Bani Hawazin that persisted for four years, and a treaty was finally signed. Subsequently the treaty, an association named Hilf al-Fudu,l (The Pact of the Virtuous) was designed to crisscross more ferocity and bias; and to stance on the side of the subjugated, a word was reserved by the offspring of Banu Hashim and the allied kin, where Muhammad (PBUH) was correspondingly a fellow (Ramadan 2007: 21, Khan 1998: 16). In far ahead times of his life, Muhammad (PBUH) is informed to have held about this agreement, "I witnessed a confederacy in the house of 'Abdullah bin Jada'an. It was more appealing to me than herds of cattle. Even now in the period of Islam, I would respond positively to attending such a meeting if I were invited" (Al-Mubarakpuri 2002: 77). Al-Olaqi, states that "the Prophet is the personification of divine compassion, one sent by Allah as a mercy for all worlds. Prophet Muhammad (PBUH) is like a source of light in an all-omnipresent gloom; whoever insists to this spring can take as much water as required to please their thirst, to become purified of all their sins, and to become lighted with the light of faith; and Muhammad's kindness was like a magic key in his hands; for with it, he opened hearts that were so combined and dulled that no one thought they could be opened" (Al-Olaqi 2015: 63).

Brilliant Western writers such as Craig Considine and Karen Armstrong are real peacebuilders the world needs. Consequently, their attitude towards the divine message of Prophet Muhammad (PBUH) is an extension of the previous Christian views towards the evangelic prophets. Considine and Armstrong overcome the traditional Christian polemical claims on Muhammad to prove that he was a mere human with no Divine intervention in his life, and hence he could not be a prophet. For the people of the Western World who wish to understand Prophet Muhammad (PBUH), his human character, his ethnic background and stereotype, they unjustly fail to understand the divine revelation to the Prophet and Muhammad's Prophethood (PBUH). For instance, in a comparable phase Considine finds out that:

The most important bond that Jesus Christ and Prophet Muhammad share is their love for humanity. Both cared for other people and groups as much as their own followers. Jesus taught his followers to "Honor all people, love the brotherhood" (1 Peter 2:17). Christ's love for humanity is also seen in Philippians (2:1-2), which 
calls on human beings to comfort and love one another and to be of 'one accord, of one mind'. Prophet Muhammad repeated Jesus's love for humanity in stating "All God's creatures are His family" (Al-Bukhari). He added: "None of you (truly believe) until he wishes for his brother what he wishes for himself" (Al-Bukhari). Christ and the Prophet did not call for discord and separation. Harmony and unity in society were much more important to them. ${ }^{4}$

One of the mutual typecasts about Prophet Muhammad is to consider him as a devout person appealing Prophethood, and devoted his time to serve the Arabs, the polytheists of the Arabian Peninsula, from their worthless age. This point of view extremely oversees his time accomplishments and his influence on the antiquity of human race. Watt remarks that "none of the great figures of history is so poorly appreciated in the West as Muhammad" (Watt 1953: 52). In his book The Life and Teachings of Muhammad, Annie Besant concludes that "it is impossible for anyone who studies the life and character of the great Prophet of Arabia, who knows how he taught and how he lived, to feel anything but reverence for that mighty Prophet, one of the great messengers of the Supreme. And although in what I put to you I shall say many things which may be familiar to many, yet I myself feel whenever I re-read them, a new way of admiration, a new sense of reverence for that mighty Arabian teacher" (Besant 1932: 4). The human messages of Prophet Muhammad and Prophet Jesus Christ are the peacebuilding mission to endorse tolerance in the World.

Craig Considine acknowledged his appreciation with a passionate contest of Prophet Muhammad and Prophet Jesus the Christ. For instance, Considine says that "Jesus and Muhammad forgave their enemies because God is not harsh or revengeful, but rather mild and gentle" (Ibid). In the Western research institutions, peacebuilding initiatives stock a great recognition of many similarities among the religious teachings of Jews, Christians, and Muslims. Early pioneer academicians such as William Watt, Daniel Norman and David S. Margoliouth appreciated the Prophet's teachings such as the equality of all Muslims as a fundamental doctrine of Islam. And the assumption of the earliest interpretations that the Prophet's family lived a simple life with no privileges is true. The Prophet's own position was, of course, exceptional. But it is not an exaggeration to say that he would seem to have regarded the ideal brotherhood of Islam as superior in closeness to all family ties (Margoliouth 1928: 79-80). Margoliouth respected the Prophet's principle of Islamic brotherhood in saying that "we must obey God rather than men", is therefore the formula which underlies the Islamic system prudence must not be forgotten (1928: 111-112). Consequently, Muslims are usually decent partners in the quality of tolerance.

${ }^{4}$ Published on Huffington Post (24.04.2015). Available online at $<\mathrm{https}$ ://craigconsidinetcd. com/2015/04/24/jesus-christ-and-prophet-muhammad-followed-the-golden-rule/>. Accessed on 07.08.2021. 


\section{Conclusion}

The peaceful transformation of attitudes towards Islam adjusts misinformation that may help displace awful hatred against Muslims. Prophet Muhammad (PBUH) has gained admiration and respect by many intellectuals after a long journey of research and investigation. They have examined the life of this divinatory personality and reached in their works to the reality and classified the Great Prophet as one among heroes and figures that the world has never seen. The gradual change of the reputation of the Noble Muhammad is the result of thorough research and investigation of the life of the Messenger and his great humanity.

In today's world of pluralism and multiculturalism, a Western peacebuilding phase towards Islam is essential for adherents of different religions to coexist in peace and harmony. Muslims, Jews, and Christians must understand the tolerant message of religion and the great role models of the prophets. The alteration of the image of Islam is making scholarly awareness and investigation. Compared to Prophet Jesus, Western academic attitude in the direction of Muhammad (PBUH) emphases on the Prophet as a man without any insignificant situation to the intention and objective of the divine message.

The growing emphasis on academic success and school accountability makes information about Prophet Muhammad and Islam more reliable. Prophet Muhammad (PBUH) is still an enormous sort of inspiration for mankind. His tradition and the Qur'an are massive sources of human knowledge in science and social sciences. $\mathrm{He}$ is the best sample for the East and the West in his human values and insights. In addition, it is essential for appropriate message and an expressive discourse of cultures between the Islamic world and the Christian world. Aimed at better Christian-Muslim friendship overlays the means for a nonviolent worldwide peace and justice at all stages and in all matters. The general Western academy plays its substantial part in promoting a peaceful and tolerant world.

\section{Acknowledgements}

This work was funded by the Deanship of Scientific Research (DRS), University of Jeddah, Jeddah, Saudi Arabia Kingdom, under grant No. (UJ-20-005-SAI). The author, therefore, acknowledges with thanks DSR technical and financial support.

This work was also funded by the Deanship of Scientific Research (DSR), King Abdulaziz University, Jeddah, under grant No. (857-001-D1434). The author, therefore, acknowledges with thanks DSR technical and financial support. 
Address:

Fahd Mohammed Taleb Saeed Al-Olaqi

Department of English \& Translation

Faculty of Science \& Arts -Khulais

University of Jeddah

Jeddah, Kingdom of Saudi Arabia

E-mail: falolaqi@uj.edu.sa

\section{References}

Al-Bokhari, M. (1991) Sharah Fatah Al-Bary; Saheh Al-Bokhari. Eygpt, Dar Al-Nahdha.

Al-Mubarakpuri, Safiur-Rahman (2002) The sealed nectar. Saudi Arabia, Um Aqura.

Ali, Abdullah Yusuf, trans. (1997) The Glorious Qur'an. AL-Madina: Mujama King Fahd.

Al-Olaqi, Fahd (2015) “The Prophet Muhammad's leadership: an Islamic view". Advances in Social Sciences Research Journal 2, 9, 59-70.

Al-Olaqi, Fahd (2016) "Western polemic writings about Muhammad's Prophethood." Advances in Social Sciences Research Journal 3, 5, 138-156. DOI: 10.14738/assrj.35.2001

Armstrong, Karen (1992) Muhammad: a Western attempt to understand Islam. London: Victor Gollancz Ltd.

Armstrong, Karen (2006) Muhammad a Prophet of our time. Harper Collins.

Besant, Annie (1932) The life and teachings of Muhammad. India, Madras.

Carlyle, Thomas (2001) On heroes, hero-worship, and the heroic in history. A Penn State Electronic Classic Series Publications.

Considine, Craig (2015) "Jesus Christ and Prophet Muhammad followed "The Golden Rule". Huffington Post, 21 June.

Considine, Craig (2016) "Christians and Muslims should embrace 'The Jihad of Jesus,' Huffington Post, 31 May.

Considine, Craig (2016) "Religious Pluralism and Civic Rights in a 'Muslim nation': an analysis of Prophet Muhammad's covenants with Christians". Religions 7, 2, 15.

Considine, Craig (2017) "Why a Christian can view Muhammad as a Prophet". Huffington Post, 26 January.

Crone, Patricia (1987) Meccan trade and the rise of Islam. Princeton: Princeton University Press.

Daniel, Norman (1960) Islam, Europe and Empire. Edinburgh: Edinburgh University Press.

Daniel, Norman (1993) Islam and the West: the making of an image. Oxford: Oneworld.

Draper, John W. (1875) A history of the intellectual development of Europe. Vol. 1. London.

Forward, Martin (1997) Muhammad: a short biography. Oxford: Oneworld.

Gibbon, Edward and Simon. Ocklay (1870) History of the Saracen Empire. London.

Khan, Majid Ali (1998) Muhammad the final messenger. India: Islamic Book.

Khan, Saeed Sharafat and Fahd Al-Olaqi (2020) "Western image of Muhammad (PBUH) as a Prophet". Trames 24, 1, 71-94.

Lamartine, Alphonse de (1854) Histoire de la Turquie. Vol 2. Paris.

Laqueur, Walter (2006) The changing face of Anti-Semitism: from ancient times to the present day. Oxford University Press.

Margoliouth, David (1928) Mohammedanism. London: Thornton Butterworth Ltd. 
Michener, James (1955) “Islam: the misunderstood religion”. In Reader's Digest (American edition), May.

Ramadan, Tariq (2007) In the footsteps of the Prophet: lessons from the life of Muhammad. New York: Oxford University Press.

Parrinder, Geoffrey (1976) Mysticism in the world's religions. New York: Oxford University Press.

Stubbe, Henry (1954) An account of the rise and progress of Mahometanism; with the life of Mahomet, and a vindication of him and his religion from the calumnies of the Christians; by Henry Stubbe. From a manuscript copied by Charles Hornby of Pipe Office, in 1705, with some variations and additions. Edited with an introd. and appendix by Hafiz Mahmud Khan Shairani. Lahore: Orientalia.

Vitkus, Daniel J. (1999) Orientalism. Early Modern Orientalism: representations of Islam in sixteenthand seventeenth century Europe. Supplied by The British Library - "The world's knowledge".

Vitkus Daniel J. (1999) "Early Modern Orientalism: representations of Islam in sixteenth- and seventeenth-century Europe”. In D. R. Blanks and M. Frassetto, eds. Western views of Islam in Medieval and Early Modern Europe. New York: Palgrave Macmillan. DOI: https://doi. org/10.1057/9780312299675_12

Watt, William Montgomery (1953) Muhammad at Mecca. Oxford: Oxford University Press.

Watt, William Montgomery (1961) Muhammad, Prophet and statesman. Oxford: Oxford University Press. 